\title{
TRANSMISI DAN EKSPRESI FENOTIPE GEN PENYANDI HORMON PERTUMBUHAN PADA IKAN PATIN SIAM
}

\author{
Raden Roro Sri Pudji Sinarni Dewi, Jadmiko Darmawan, dan Ika Nurlaela \\ Balai Penelitian Pemuliaan Ikan \\ Jl. Raya 2 Sukamandi, Subang 41256 \\ E-mail: wiewie_thea@yahoo.com
}

(Naskah diterima: 31 Desember 2013; Disetujui publikasi: 17 Maret 2014)

\begin{abstract}
ABSTRAK
Ikan patin siam merupakan salah satu ikan budidaya air tawar yang memiliki nilai ekonomis tinggi di Indonesia. Transfer gen pCcBA-PhGH pada ikan patin siam bertujuan untuk mempercepat pertumbuhan dan meningkatkan produksi ikan patin siam. Pada penelitian ini dilakukan evaluasi terhadap tingkat transmisi dan ekspresi fenotipe gen pCCBA-PhGH pada generasi pertama (F1) ikan patin siam. Generasi F1 ikan patin siam supergrowth dihasilkan dengan cara mengawinsilangkan antara induk jantan ikan patin siam yang membawa gen $\mathrm{pCcBA}-\mathrm{PhCH}$ (ikan patin siam supergrowth generasi F0) dengan induk betina ikan patin siam non-supergrowth. Sebagai populasi kontrol dilakukan persilangan antara sesama induk jantan dan betina non-supergrowth. Hasil persilangan antara induk jantan ikan patin siam supergrowth generasi F0 dengan induk betina ikan patin siam non-supergrowth menghasilkan derajat pembuahan (FR) sebesar $78,8 \pm 4,85 \%$ dan derajat penetasan (HR) sebesar $97,9 \pm 0,85 \%$ relatif lebih tinggi dibandingkan kontrolnya (FR: $38,5 \pm 0,96 \%$; HR: 89,6 $\pm 3,05 \%$ ). Tingkat transmisi gen pCcBA-PhGH dari generasi F0 ke generasi F1 adalah sebesar $66,7 \%$. Selama empat bulan pemeliharaan di kolam, populasi ikan patin siam supergrowth generasi F1 tumbuh 47,5\% lebih cepat dibandingkan populasi kontrol. Adapun biomassa populasi ikan patin siam supergrowth generasi F1 70,5\% lebih tinggi dibandingkan kontrol.
\end{abstract}

KATA KUNCl: ikan patin siam, transmisi, ekspresi, gen penyandi hormon pertumbuhan

ABSTRACT: Transmission and phenotypic expression of growth hormone encoding gene on Pangasionodon hypophthalmus. By: Raden Roro Sri Pudji Sinarni Dewi, Jadmiko Darmawan, and Ika Nurlaela

Stripped catfish (Pangasianodon hypophthalmus) is one of freshwater species that has highly economic value in Indonesia. Transfer of pCCBA-PhGH gene on stripped catfish was aimed to increase its growth and production. This research was conducted to evaluate transmission and phenotypic expression of pCCBA-PhGH on Fl generation of stripped catfish. The Fl generation of supergrowth stripped catfish (SG 1) was produced by mating the male of supergrowth (SG) stripped catfish FO generation (carrying pCCBA-PhGH gene) with wild female. For control population, wild male was crossed with wild female. Fertilization rate (FR) and hatching rate (HR) on SG 1 were $78.8 \pm 4.85 \%$ and $97.9 \pm 0.85 \%$, they were relatively higher than control population (FR and $H R$ were $38.5 \pm 0.96 \%$ and $89.6 \pm 3.05 \%$ ). Transmission rate of $P C c B A-P h G H$ gene from FO to Fl generation was 66.7\%. After four months reared in pond, growth of SG 1 was $47.5 \%$ faster than control. However, biomass of SG 1 was $70.5 \%$ higher than control.

KEYWORDS: Pangasianodon hypophthalmus, transmission, expression, growth hormone encoding gene 


\section{PENDAHULUAN}

Transfer gen penyandi hormon pertumbuhan pada ikan terbukti mampu mempercepat pertumbuhan beberapa spesies ikan budidaya antara lain pada ikan nila (Kobayashi et al., 2007); ikan mas (Hinits \& Moav, 1999); ikan mud loach (Nam et al., 2001); ikan salmon Atlantik (Du et al., 1992); dan sebagainya. Hormon pertumbuhan adalah polipeptida yang sangat penting untuk pengaturan pertumbuhan pada vertebrata (Meier et al., 2006). Hormon pertumbuhan pituitari juga dikenal sebagai somatotropin pada ikan, dan merupakan protein kunci yang berperan dalam pengaturan pertumbuhan somatik dan banyak aspek metabolisme yang terdeteksi pada semua vertebrata (Ryynanen \& Primmer, 2006). Pada ikan, hormon pertumbuhan terlibat dalam sejumlah proses fisiologi termasuk keseimbangan ionik, metabolisme lipid dan protein, pertumbuhan, reproduksi, dan fungsi kekebalan, serta berbagai aspek tingkah laku (Perez-Sanchez, 2000). Melalui transfer gen penyandi hormon pertumbuhan memungkinkan organisme memproduksi hormon pertumbuhan dalam jumlah yang lebih besar karena hormon pertumbuhan diproduksi tidak hanya di kelenjar pituitari tetapi dapat juga diproduksi di organ lainnya sesuai dengan promoter yang digunakan.

Ikan patin siam merupakan salah satu komoditas ikan budidaya air tawar yang memiliki nilai ekonomis tinggi di Indonesia. Upaya peningkatan produksi ikan patin siam menuntut adanya ketersediaan induk/benih unggul terutama pada karakter pertumbuhan. Pemanfaatan teknologi transfer gen pada ikan patin siam diharapkan mampu menghasilkan ikan patin siam yang memiliki pertumbuhan cepat (supergrowth). Transfer gen penyandi hormon pertumbuhan ikan patin siam (Pangasianodon hypophthalmus growth hormone, $\mathrm{PhCH}$ ) yang disambungkan dengan promoter $\beta$-aktin ikan mas ( $\mathrm{c} C \mathrm{BA}$ ) menunjukkan bahwa gen pCcBA-PhGH mampu terinsersi dan terekspresi pada ikan patin siam (Dewi et al., 2012). Pada ikan patin siam supergrowth generasi FO umur sepuluh bulan, bobot ratarata mencapai $539 \mathrm{~g}$ dengan bobot ikan terbesar mencapai $745 \mathrm{~g}$ sedangkan bobot rata-rata kontrol adalah $346 \mathrm{~g}$ dengan bobot ikan terbesar 435 gram (Dewi, 2011).

Penelitian ini bertujuan untuk menentukan tingkat transmisi gen pCCBA-PhGH pada ikan patin siam supergrowth generasi $\mathrm{Fl}$, serta efeknya terhadap derajat pembuahan, derajat penetasan, dan pertumbuhan. Informasi yang didapatkan dari penelitian ini diharapkan dapat memberikan gambaran mengenai potensi pengembangan budidaya ikan patin siam supergrowth.

\section{BAHAN DAN METODE}

\section{Produksi Populasi Ikan Patin Siam Supergrowth dan Kontrol}

Ikan patin siam supergrowth generasi $\mathrm{F} 1$ (SG 1) merupakan hasil persilangan antara induk betina ikan patin siam non-supergrowth (non-SG) dengan induk jantan supergrowth generasi F0 (SG 0). Ikan patin siam yang dijadikan populasi kontrol merupakan hasil persilangan antara induk betina ikan patin siam non-SG dengan induk jantan non-SG. Populasi SG 1 dan populasi kontrol berasal dari induk betina ikan patin siam yang sama. Masingmasing persilangan diulang dua kali. Ikan patin siam SG 0 merupakan ikan patin siam yang telah ditransfer gen pCcBA-PhGH (Dewi et al., 2012).

Pemijahan induk betina dan jantan dilakukan secara buatan. Induksi pematangan gonad ikan patin siam betina dilakukan melalui penyuntikan hormon HCG, sedangkan untuk merangsang ovulasi dilakukan melalui penyuntikan ovaprim. Induksi spermiasi pada ikan patin siam jantan dilakukan melalui penyuntikan ovaprim. Telur dan sperma diperoleh melalui proses stripping. Sperma dilarutkan dalam larutan fisiologis selanjutnya dicampurkan dengan telur. Penambahan air dilakukan untuk mengaktifkan sperma agar dapat membuahi sel telur. Sel telur yang telah dibuahi selanjutnya diinkubasi di dalam akuarium.

\section{Parameter yang Diukur}

\section{Derajat pembuahan dan derajat penetasan}

Derajat pembuahan (fertilization rate, FR) dihitung empat jam setelah pembuahan. Adapun derajat penetasan (hatching rate, HR) dihitung 24 jam setelah pembuahan. Pengamatan FR dan HR dilakukan sebanyak dua ulangan dari setiap persilangan. Derajat pembuahan dihitung dengan menggunakan rumus : [Jumlah telur yang dibuahi/Jumlah total telur) $\times 100 \%$ ]. Derajat penetasan dihitung dengan menggunakan rumus: [ Jumlah telur yang menetas/Jumlah telur yang dibuahi) $x$ 100\%)]. 


\section{Transmisi gen pCCBA-PhGH}

Transmisi gen $\mathrm{pCcBA}-\mathrm{PhGH}$ pada populasi ikan patin siam SG 1 dilakukan dengan cara mendeteksi keberadaan gen $\mathrm{PhGH}$ pada fase yuvenil. Deteksi gen PhCH eksogen (transgen) dilakukan dengan menggunakan metode PCR (Polymerase Chain Reaction). Deteksi keberadaan transgen dilakukan dengan memotong sebagian sirip ekor yuwana ikan patin siam untuk kemudian dilakukan ekstraksi DNA genom. PCR dilakukan menggunakan primer FphGH1 (5'-TAG AGT GTT GGT GGT GCT CTC TGT-3') dan RphGH2 (5'-CGA TAA GCA CGC CGA TGC CCA TTT-3'). Ukuran fragmen gen $\mathrm{PhGH}$ eksogen produk PCR adalah $392 \mathrm{bp}$.

\section{Pertumbuhan, sintasan, dan biomassa}

Benih ikan patin siam dari populasi SG 1 dan kontrol dipelihara secara terpisah di kolam tanah berukuran $100 \mathrm{~m}^{2}$. Kepadatan yang digunakan 5 ekor $/ \mathrm{m}^{2}$. Pakan yang diberikan berupa pelet komersial dengan kadar protein 28\%-30\% yang diberikan dua kali sehari secara at satiation. Pemeliharaan dilakukan selama empat bulan. Bobot ikan patin siam diukur setiap bulan. Sintasan dan bobot biomassa dihitung pada akhir pemeliharaan dengan cara menghitung jumlah dan bobot individu yang tertangkap.

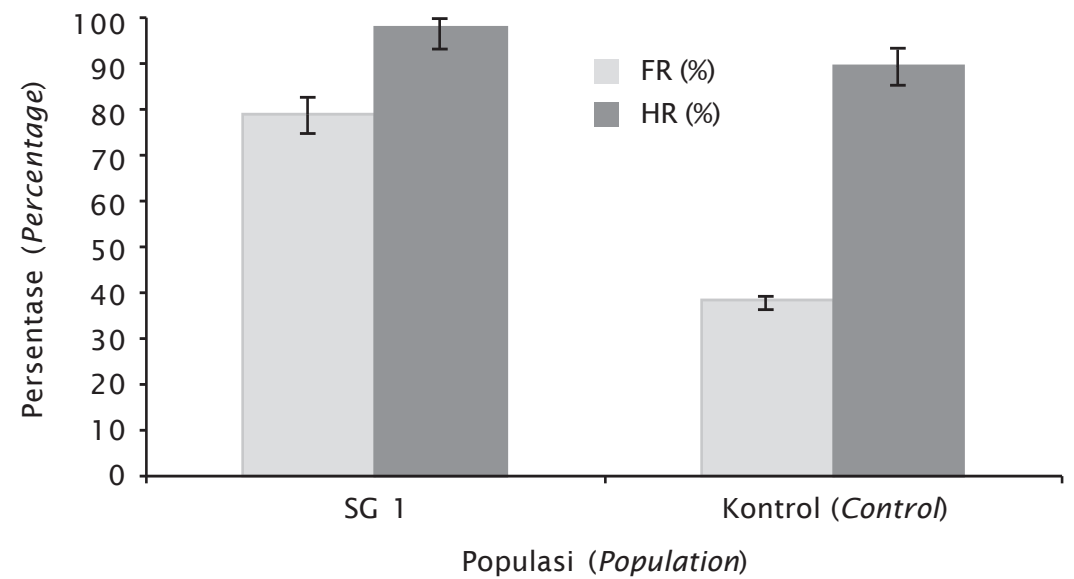

Gambar 1. Derajat pembuahan (FR) dan derajat penetasan (HR) pada populasi hasil persilangan antara induk betina ikan patin siam nonsupergrowth dengan induk jantan ikan patin siam supergrowth generasi F0 (SG 1) dan non-supergrowth (kontrol)

Figure 1. Fertilization rate (FR) and hatching rate (HR) on $F 1$ generation crossed between wild female with male of supergrowth stripped catfish FO generation (SG 1) and wild male (control)

\section{HASIL DAN BAHASAN}

\section{Hasil Penelitian}

Derajat pembuahan dan derajat penetasan ikan patin siam supergrowth dan kontrol

Kualitas sperma ditentukan antara lain oleh kemampuan sperma membuahi sel telur. Berdasarkan data yang tertera pada Gambar 1 bahwa derajat pembuahan dan derajat penetasan pada embrio yang berasal dari induk jantan ikan patin siam SG 0 cenderung lebih baik dibandingkan kontrol. Hal ini menunjukkan bahwa penyisipan gen $\mathrm{pCcBA}$-PhGH pada sperma ikan patin siam tidak menurunkan Transmisi gen pCCBA-PhGH pada ikan patin siam supergrowth generasi $\mathrm{F} 1$

Transfer gen pCcBA-PhGH pada ikan patin siam diharapkan mampu ditransmisikan pada keturunannya. Pada penelitian ini, pemeriksaan keberadaan gen $\mathrm{PhGH}$ pada yuwana ikan patin siam yang merupakan hasil persilangan antara induk betina ikan patin siam non-SG dengan induk jantan SG 0 terdeteksi pada ukuran 392 bp (Gambar 2). Transmisi gen pCcBA-PhGH eksogen pada ikan patin siam supergrowth generasi F1 adalah sebesar 66,7\% (Tabel 1). 


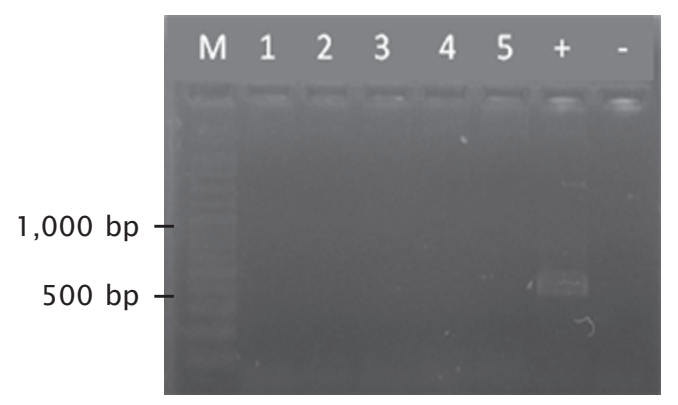

Kontrol (Control)

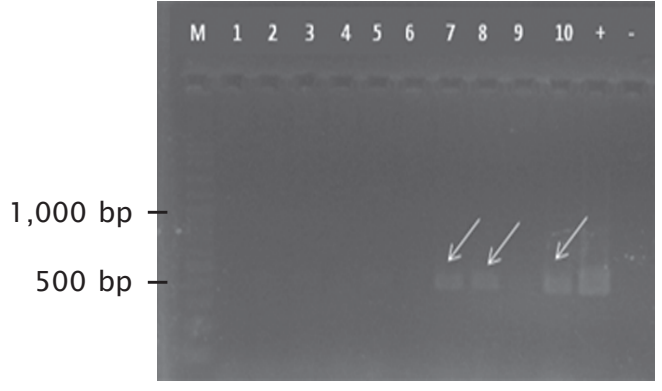

SG 1

Gambar 2. Deteksi gen PhGH eksogen pada populasi kontrol dan ikan patin siam supergrowth generasi F1 (SG 1). ( $M$ = marker; 1-4 dan 1-10= nomor individu; + = kontrol positif (plasmid pCcBA-PhGH); - = kontrol negatif (tanpa cetakan DNA); tanda panah = fragmen gen $\mathrm{PhGH}$ eksogen)

Figure 2. Detection of exogenous PhGH gene on control and supergrowth stripped catfish Fl generation population (SG 1). ( $M=$ marker; $1-4$ and $1-10=$ number of individuals; $+=$ positive control ( $p C c B A-P h G H$ plasmid); - = negative control (without DNA template); arrows $=$ PhGH exogenous gene fragment)

Tabel 1. Transmisi gen $\mathrm{pCCBA}-\mathrm{PhGH}$ pada ikan patin siam supergrowth generasi $\mathrm{F} 1$

Table 1. Transmission of $P C C B A-P h G H$ gene on supergrowth stripped catfish F1 generation

\begin{tabular}{|c|c|c|c|}
\hline \multirow[t]{2}{*}{$\begin{array}{c}\text { Populasi } \\
\text { Population }\end{array}$} & \multirow{2}{*}{$\begin{array}{l}\text { Jumlah individu yang } \\
\text { diperiksa (Ekor) } \\
\text { Number of sample } \\
\text { analyzed (Fish) }\end{array}$} & \multicolumn{2}{|c|}{$\begin{array}{c}\text { Jumlah individu yang posit if membaw } \\
\text { transgen (Number of fish positively } \\
\text { carrying transgene) }\end{array}$} \\
\hline & & Ekor (Fish) & $\%$ \\
\hline SG 1 & 30 & 20 & 66.7 \\
\hline Kontrol (Control) & 30 & 0 & 0 \\
\hline
\end{tabular}

Pertumbuhan, sintasan, dan biomassa ikan patin siam supergrowth dan kontrol

Berdasarkan data pada Gambar 3, pertumbuhan populasi ikan patin siam SG 1 pada bulan pertama cenderung lebih rendah dibandingkan dengan kontrol. Pada pengamatan bulan kedua sampai bulan keempat, kecepatan pertumbuhan populasi ikan patin siam SG 1 cenderung lebih cepat dibandingkan dengan kontrol. Kecepatan pertumbuhan populasi ikan patin siam SG 1 pada bulan keempat pemeliharaan 47,5\% lebih cepat dibandingkan populasi kontrol.

Sintasan populasi ikan patin siam SG 1 dan kontrol pada bulan keempat pemeliharaan cenderung tidak berbeda (Tabel 2). Pertambahan bobot biomassa populasi ikan patin SG 1 70,5\% lebih berat dibandingkan populasi kontrol.

\section{Bahasan}

Integrasi transgen pada genom yang terjadi setelah fase satu sel menyebabkan terjadinya fenomena mosaik. Mosaik dapat terjadi pada sel somatik dan sel gonad. Pada penelitian ini, transmisi gen $\mathrm{pCCBA}-\mathrm{PhCH}$ dari founder (F0) kepada keturunannya yaitu sebesar $66,7 \%$. Pada spesies ikan lain, transmisi transgen pada generasi $\mathrm{Fl}$ sangat bervariasi. Transmisi gen pFV-1/csGH hasil persilangan antara ikan mas jantan transgenik dengan betina non-transgenik yaitu sebesar 12,5\%-63\% (Moav et al., 1995). Transmisi gen MThGH pada hasil persilangan antara ikan mas jantan transgenik dengan betina non-transgenik adalah sebesar 72\%-88\% (Wu et al., 2003). Tingkat transmisi gen ZpßypGH pada ikan zebra generasi $\mathrm{F} 1$ yaitu 53\% (Sheela et al., 1998) lebih rendah dibandingkan hasil penelitian 


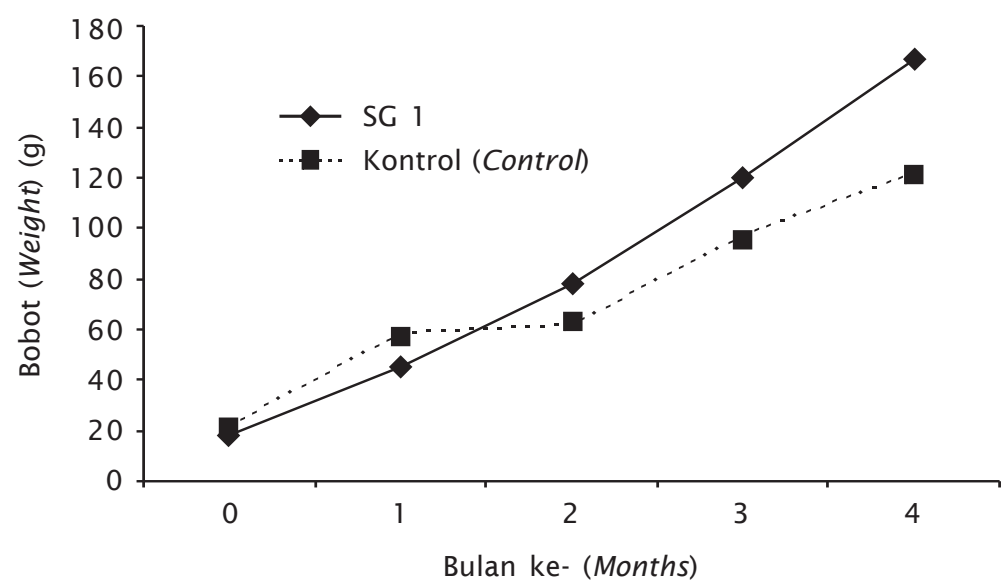

Gambar 3. Pertumbuhan populasi ikan patin siam supergrowth generasi F1 (SG 1) dan kontrol selama empat bulan pemeliharaan

Figure 3. Growth of supergrowth stripped catfish Fl generation and control population for four months rearing

Tabel 2. Sintasan dan biomassa ikan patin siam supergrowth generasi F1 (SG 1) dan kontrol

Table 2. Survival rate (SR) and biomass of supergrowth stripped catfish Fl generation (SG 1) and control

\begin{tabular}{lcc}
\hline \multicolumn{1}{c}{ Paramet er (Paramet ers) } & SG $\mathbf{1}$ (SG 1) & Kont rol (Control) \\
\hline Bobot awal (Initial weight) (g) & $18 \pm 9$ & $21 \pm 14$ \\
Bobot akhir (Final weight) (g) & $167 \pm 64$ & $121 \pm 59$ \\
Sintasan (Survival rate) (\%) & 48.8 & 48 \\
Biomassa awal (Initial biomass) (g) & 9.000 & 10.500 \\
Biomassa akhir (Final biomass) (g) & 40.824 & 29.168 \\
\hline
\end{tabular}

Inou et al. (1990) pada ikan medaka; tingkat transmisi transgen pada ikan medaka generasi $\mathrm{F} 1$ adalah $100 \%$.

Transfer gen hormon pertumbuhan ikan patin siam telah berhasil meningkatkan pertumbuhan ikan patin siam. Pada ikan patin siam SG 0 umur empat bulan (pembesaran dua bulan di kolam), kecepatan pertumbuhan mencapai 53,38\% dibandingkan kontrol (Dewi et al., 2012). Pada umur sepuluh bulan (pembesaran delapan bulan di kolam), kecepatan pertumbuhan populasi ikan patin siam SG 0 mencapai 56\% lebih tinggi dibandingkan kontrol dengan pertumbuhan ikan patin siam SC 0 tercepat mencapai $115 \%$ lebih cepat dibandingkan rata-rata kontrol dan 71\% lebih cepat dibandingkan ikan kontrol yang terbesar (Dewi, 2011). Perbaikan karakter pertumbuhan pada ikan patin siam SG 0 berhasil diwariskan pada keturunannya. Pada ikan patin siam SG 1 yang dibesarkan selama empat bulan di kolam, kecepatan pertumbuhannya mencapai $47,5 \%$ lebih tinggi dibandingkan kontrol.

Peningkatan pertumbuhan pada ikan patin siam SG 1 serupa dengan ikan mas yang ditransfer gen MThGH. Transfer gen MThGH pada ikan mas mampu mempercepat pertumbuhannya. Pada ikan mas MThGH generasi F0 umur empat bulan, bobot rata-ratanya mencapai 2,75 kg sedangkan bobot ikan mas kontrol yang terbesar adalah 1,4 kg (Wang et al., 2001). Pada ikan mas transgenik MThGH generasi $\mathrm{F} 1$, rata-rata pertumbuhannya $42 \%$ $80 \%$ lebih cepat dibandingkan kontrol (Wu et al., 2003). 
Pertumbuhan ikan patin siam SG 1 yang lebih cepat dibandingkan kontrolnya diiringi dengan peningkatan biomassanya. Selama empat bulan pemeliharaan, peningkatan bobot biomassa populasi ikan patin siam SG 1 70,5\% lebih berat dibandingkan populasi kontrolnya. Peningkatan bobot biomassa yang signifikan pada populasi ikan patin siam SG 1 memberikan harapan untuk meningkatkan produksi ikan patin siam di masa mendatang.

Efek peningkatan pertumbuhan yang signifikan pada ikan yang disisipi gen penyandi hormon pertumbuhan disebabkan karena transfer gen penyandi hormon pertumbuhan akan meningkatkan kadar hormon pertumbuhan di dalam tubuh ikan. Level hormon pertumbuhan yang tinggi di dalam tubuh ikan akan menginduksi sintesis insulin like growth factor-I (IGF-I) di hati dan selanjutnya IGF-I akan menstimulasi otot untuk mensintesis protein. Selain memengaruhi sekresi IGF-I, hormon pertumbuhan juga dapat langsung menstimulasi otot untuk menyintesis protein. Beberapa faktor ini, diduga menyebabkan beberapa individu yang disisipi gen penyandi hormon pertumbuhan berukuran lebih besar dibandingkan kontrol (Devlin et al., 2009).

Potensi tumbuh ikan yang disisipi gen penyandi hormon pertumbuhan yang lebih cepat dibandingkan dengan kontrol perlu didukung oleh kondisi lingkungan yang optimal, nutrisi yang mencukupi, dan kondisi ikan yang sehat. Penelitian Guan et al. (2008) pada ikan mas menunjukkan bahwa konsumsi pakan ikan mas yang disisipi gen penyandi hormon pertumbuhan 2,12 kali lebih besar dibandingkan yang kontrol. Begitu pula konsumsi oksigen ikan mas yang disisipi gen penyandi hormon pertumbuhan 1,33 kali lebih besar dibandingkan kontrol. Namun pada saat dipuasakan selama 96 jam, konsumsi oksigen ikan mas yang disisipi gen penyandi pertumbuhan, dan kontrol tidak berbeda. Hal ini dapat dijadikan acuan pada ikan patin siam supergrowth, di mana pertumbuhan ikan patin siam supergrowth diduga dapat meningkat lebih cepat apabila diberi pakan dan kondisi lingkungan yang optimal.

\section{KESIMPULAN}

Gen $\mathrm{pCcBA}$-PhGH pada ikan patin siam supergrowth berhasil ditransmisikan dari generasi F0 ke generasi $F 1$ sebesar $66,7 \%$. Ekspresi fenotipe gen pCcBA-PhCH pada ikan patin siam supergrowth generasi F1 mampu meningkatkan pertumbuhan sampai $47,5 \%$ dibandingkan kontrol. Pertambahan biomassa pada ikan patin siam supergrowth generasi F 1 $70,5 \%$ lebih tinggi dibandingkan populasi kontrol.

\section{DAFTAR ACUAN}

Devlin, R.H., Sakhrani, D., Tymchuk, W.E., Rise, M.L., \& Goh, B. 2009. Domestication and growth hormone transgenesis cause similar changes in gene expression in coho salmon (Oncorhynchus kisutch). Proc. Natl. Acad. Sci. USA, 106(9): 3,047-3,052.

Dewi, R.R.S.P.S. 2011 . Transfer gen melalui perantaraan sperma untuk memproduksi ikan transgenik. Prosiding Konferensi Akuakultur Indonesia 2011 , hlm. 372-378.

Dewi, R.R.S.P.S., Alimuddin, Sudrajat, A.O., \& Sumantadinata, K. 2012. Efektivitas transfer dan ekspresi gen $P h G H$ pada ikan patin siam (Pangasianodon hypophthalmus). J. Ris. Akuakultur, 7(2): 171-180

Du, S.J., Gong, Z., Fletcher, G.L., Shears, M.A., King, M.J., Idler, D.R., \& Hew, C.L. 1992. Growth enhancement in transgenic Atlantic salmon by the use of an "all fish" chimeric growth hormone gene construct. Biol. Tech., 10: 176-180.

Guan, B., Hu, W., Zhang, T., Wang, Y., \& Zhu, Z. 2008. Metabolism traits of "all-fish" growth hormone transgenic common carp (Cyprinus carpio L.). Aquaculture, 284: 21 7-223.

Hinits, Y. \& Moav, B. 1999. Growth performance studies in transgenic Cyprinus carpio. Aquaculture, 173: 285-296.

Inoue, K., Yamashita, S., Hata, J., Kabeno, S., Asada, S., Nagahisa, E., \& Fujita, T. 1990. Electroporation as a new technique for producing transgenic fish. Cell. Differ. Dev., 29: 123-128.

Kobayashi, S., Alimuddin, Morita, T., Miwa, M., Lu, J., Endo, M., Takeuchi, T., \& Yoshizaki, G. 2007. Transgenic nile tilapia (Oreochromis niloticus) over expressing growth hormone show reduced ammonia excretion. Aquaculture, 270: 427-435.

Meier, K.M., Castano, C., Laurino, J., Levy, J.A., \& Marins, L.F. 2006. cDNA cloning and phylogenetic analysis of growth hormone genes from the mullet Mugil platanus (Mugilomorpha, mugilidae) and the halfbeak Hemiramphus brasiliensis (Atherinomorpha, Hemiramphidae). Atlantica, 28: $97-$ 102.

Moav, B., Hinits, Y., Groll, Y., \& Rothbard, S. 1995. 
Inheritance of recombinant carp $\beta$-actin/ $\mathrm{GH}$ cDNA gene in transgenic carp. Aquaculture, 137: 179-185.

Nam, Y.K., Noh, J.K., Cho, Y.S., Cho, H.J., Cho, K.N., Kim, G., \& Kim, D.S. 2001. Dramatically accelerated growth and extraordinary gigantism of transgenic mud loach Misgurnus mizolepis. Trans. Res., 10: 353-362.

Perez-Sanchez, J. 2000. The involvement of growth hormone in growth regulation, energy homeostasis and immune function in the gilthead sea bream (Sparus aurata): a short review. Fish Physiol. Biochem., 22: 135-144.

Ryynanen, H.J. \& Primmer, C.R. 2006. Varying signals of the effects of natural selection during teleost growth hormone gene evolution. Genome, 49: 42-53.

Sheela, S.G., Chen, J.D., Mathavan, S., \& Pandian, T.J. 1998. Construction, electroporatic transfer and expression of $\mathrm{Zp} \beta y p G H$ and $\mathrm{Zp \beta rtGH}$ in zebrafish. J. Biosci., 23: 565576.

Wang, Y., Hu, W., Wu, G., Sun, Y., Chen, S., Zhang, F., Zhu, Z., Feng, J., \& Zhang, X. 2001. Genetic analysis of "all-fish" growth hormone gene transferred carp (Cyprinus carpio L.) and its F1 generation. Chin. Sci. Bull., 46: 1,174-1,177.

Wu, G., Sun, Y., \& Zhu, Z. 2003. Growth hormone gene transfer in common carp. Aquat. Living Resour., 16: 416-420. 